\title{
Analisis Pengikatan dan Gerakan Pada Dok Apung Akibat Gaya Luar dengan Variasi Desain Pengikatan di Perairan Dangkal Terbuka
}

\author{
Ahmad Charizzaka, I Ketut Aria Pria Utama, dan Teguh Putranto \\ Jurusan Teknik Perkapalan, Fakultas Teknologi Kelautan, Institut Teknologi Sepuluh Nopember (ITS) \\ Jl. Arief Rahman Hakim, Surabaya 60111 Indonesia \\ e-mail:kutama@na.its.ac.id
}

\begin{abstract}
Abstrak- Perkembangan maritim tidak lepas dari kapal sebagai sarana transportasi. Hal itu menyebabkan kebutuhan akan dok sebagai tempat pembuatan dan reparasi kapal semakin meningkat. Semakin mahalnya harga lahan dan berbagai kelebihan yang ditawarkan membuat dok apung kian diminati sebagai solusi. Dok apung sendiri sebagai suatu struktur apung tidak lepas dari pengaruh gaya luar seperti gelombang, angin, dan arus. Tugas akhir ini bermaksud untuk melakukan analisis terhadap respon gerakan dok apung akibat gaya luar, tegangan yang terjadi pada rantai pengikatan, serta tingkat kenyamanan dari dok apung itu sendiri. Analisa dilakukan dengan pemodelan secara numerik menggunakan perangkat lunak Maxsurf dan Ansys Aqwa. Pada penelitian ini, dilakukan percobaan terhadap 3 kondisi dok apung yakni saat kosong, saat kapal naik dok, dan saat kondisi balas penuh, serta dengan 3 variasi sudut datang gelombang yakni $0^{\circ}, 45^{\circ}$ dan $90^{\circ}$. Juga divariasikan konfigurasi pengikatan dok apung yakni menyilang dan menyebar. Setelah dilakukan analisis disimpulkan bahwa nilai tegangan rantai pada kondisi kosong dan kapal naik dok berada di bawah batas breaking load, sedangkan pada kondisi balas penuh tegangan yang terjadi melebihi batas breaking load baik pada desain pengikatan menyebar maupun pengikatan menyilang.Pengikatan menyilang memiliki nilai tegangan maksimum yang lebih besar dibandingkan dengan pengikatan menyebar. Tingkat ketidaknyamanan (Motion Sickness Incidence) gerakan dok apung adalah not uncomfortable atau dapat dikatakan nyaman dengan percepatan heave $0.208 \mathrm{~m} / \mathrm{s}^{2}$. Serta gerakan dok apung yang masih memenuhi kriteria dari biro klasifikasi..
\end{abstract}

Kata Kunci-Dok Apung, Motion Sickness Incidence, Respon Gerakan, Response Amplitude Operator, Tegangan Rantai Pengikatan.

\section{PENDAHULUAN}

$\mathrm{P}$ ERKEMBANGAN maritim tidak lepas dari kapal sebagai sarana transportasi. Di Indonesia sebagai salah satu negara maritim banyak terdapat galangan, baik besar maupun kecil sebagai penyedia jasa pembuatan kapal atau reparasi kapal. Terdapat beberapa teknik yang digunakan oleh jasa galangan kapal untuk pembuatan dan peluncuran kapal seperti graving dock atau sliding. Akan tetapi semakin mahalnya harga lahan di darat menjadi hambatan tersendiri bagi perkembangan industri galangan kapal dengan kedua metode tersebut. Selain itu sulitnya mencari lahan tanah dengan karakteristik yang cocok untu pembuatan graving dock juga menjada kendala bagi galangan untuk mengembangkan fasilitas pembuatan atau reparasi kapal. Oleh karena itu dok apung menjadi pilihan untuk dikembangkan oleh perusaan jasa di bidang perkapalan.

Dok apung sendiri sebagai suatu struktur apung tidak lepas dari pengaruh gaya luar seperti gelombang, angin, dan arus. Gaya gaya luar tersebut tentu akan berpengaruh pada dok apung dan membuatnya mengalami gerakan dalam 6 derajat kebebasan. Maka untuk menjaga struktur tetap pada posisinya dibutuhkan sistem pengikatan atau yang biasa disebut dengan tambat. Tali tambat yang digunakan umumnya berupa rantai (chain) dan terkadang dikombinasikan dengan kabel polyester. Pemilihan sistem tambat didasari pada kemudahan instalasi, kebutuhan tambat dan juga biaya

Gaya yang bekerja pada dok apung sangat berpengaruh terhadap rantai tambat. Gaya-gaya ini akan menjadi bebanbeban mengakibatkan rantai tambat mengalami tegangan atau disebut tension. Sehingga, diperlukan suatu analisis terhadap pengaruh gerakan yang timbul akibat gaya luar dari dok apung terhadap tegangan yang terjadi pada rantai pengikatannya serta membandingkannya dengan batas kekuatan rantai tambat tersebut.

Selain tegangan pada rantai pengikat, gerakan pada dok apung juga dapat mengakibatkan ketidaknyaamanan pada orang yang berada di atasnya. Hal ini dapat berpengaruh pada orang yang bekerja di atasnya. Sehingga perlu dilakukan pula perhitungan tingkat ketidaknyamanan pada suatu dok apung.

Dalam pemasangannya, konfigurasi rantai tambat pada dok apung memiliki beberapa variasi. Diantaranya spread straight layout (lurus) dan cross layout (menyilang). Sehingga diperlukan pula adanya analisis perbandingan pada masingmasing jenis desain layout untuk memilih desain yang lebih sesuai untuk digunakan

\section{TINJAUAN PUSTAKA}

\section{A. Gambaran Umum Dok Apung}

Dok apung adalah suatu konstruksi yang terdiri dari satu atau beberapa kompartemen kedap air pada sisi-sisinya dan terbuka pada kedua ujungnya. Dok apung dapat ditenggelamkan ke dalam air dengan cara mengisi kompartemen yang ada dengan air sehingga kapal dapat keluar masuk area dok apung tersebut. Kapal akan memasuki area tersebut saat dok apung tenggelam dan akan terangkat ketika dok apung naik ke permukaan dengan cara memompa air di dalam kompartemen ke luar. Pada umumnya dok apung 
dibuat dengan konstruksi baja. Dok apung dapat dipindahkan dari satu tempat ke tempat lain dengan cara ditarik menggunakan tugboat. Sarat dari dok apung juga dapat diatur sesuai kebutuhan dengan mengatur volume air yang ada di dalam kompartemen. Oleh karena itu sistem pontoon merupakan ciri khas dari dok apung. [6]

\section{B. Kondisi Lingkungan Laut}

Kondisi lingkungan laut sangat mempengaruhi suatu struktur apung seperti dok apung. Diantara berbagai kondisi lingkungan laut yang ada, gelombang merupakan salah satu aspek yang memiliki pengaruh besar terutama dalam gerakan strukur apung. Gelombang dapat didefinisikan sebagai suatu perubahan bentuk karena gerakan permukaan air. Selanjutnya dalam pembahasan ini setiap gelombang yang dimaksudkan adalah gelombang air laut[1]. Sebelum mempelajari lebih lanjut mengenai gelombang, terdapat beberapa istilah yang berhubungan dengan gelombang:

a) Puncak gelombang (Crest) adalah titik dimana permukaan air berada pada elevasi tertinggi.

b) Lembah gelombang (Trough) adalah titik dimana permukaan air berada pada elevasi terendah.

c) Garis datum adalah garis datar permukaan air (diambil secara statistik) pada waktu air tenang.

d) Elevasi gelombang (C) adalah jarak suatu titik pada permukaan gelombang dengan garis datum pada suatu waktu tertentu.

e) Amplitudo gelombang $(\zeta w)$ adalah garis vertikal antara titik tertinggi atau titik terendah dengan garis datum.

f) Panjang gelombang $(\lambda)$ adalah jarak dari puncak (lembah) gelombang dengan puncak (lembah) gelombang berikutnya.

g) Kecepatan gelombang $(V)$ adalah jarak yang ditempuh suatu titik per satuan waktu.

h) Frekuensi gelombang ( $\omega)$ adalah banyaknya puncak (lembah) gelombang yang dilalui oleh suatu titik per satuan waktu [1]

Selain geombang, lingkungan lain yang juga berpengaruh terhadap gerakan suatu struktur apung adalah angin. Kecepatan angin yang besar dapat menghasilkan pengaruh yang besar pula terhadap gerakan suatu dok apung. Hal lain yang juga berpengaruh adalah kecepatan arus laut

\section{Gerak Pada Dok Apung}

Secara umum gerak pada kapal dibagi menjadi dua jenis yaitu gerak translasi dan gerak rotasi dan gerak translasi.Gerak translasi adalah gerakan benda searah dengan sumbu gerakan. Sedangkan gerak rotasi adalah gerak suatu benda berputar pada sumbu putar. Karena dok apung adalah sebuah objek 3 dimensi, maka terdapat tiga sumbu gerakan yaitu sumbu $\mathrm{x}, \mathrm{y}$, dan $\mathrm{z}$. Sehingga untuk gerak translasi terdapat 3 gerakan yaitu gerakan naik dan turun searah sumbu $\mathrm{z}$ (heave), gerakan ke kiri dan ke kanan searah sumbu y (sway) dan gerakan maju mundur searah sumbu x (surge). Begitu pula dengan gerakan rotasi, terdapat 3 jenis gerakan rotasi yaitu rotasi terhadap sumbu $\mathrm{x}$ (roll), rotasi terhadap sumbu y (pitch) dan rotasi terhadap sumbu z (yaw). Sehingga secara keseluruhan terdapat 6 jenis gerakan atau biasa disebut dengan 6 derajat kebebasan (six degree of freedom). Setiap gerakan memiliki sebuah persamaan umum yang didalamnya terdapat beberapa komponen,

$a \ddot{z}+b \dot{z}+c z=F_{0} \cos \omega_{e} t$

Persamaan diatas menggambarkan gerakan heaving dan disebut sebagai forced heaving motion. Untuk gerakan translasi lainnya, persamaan tersebut dapat diterapkan dengan mengubah sumbu axis gerakan terhadap sumbu $\mathrm{x}$ dan $\mathrm{y}$, dimana a adalah virtual mass (massa kapal ditambah dengan added mass), $\mathrm{b}$ adalah koefisien damping (gaya melawan arah gerakan), c adalah koefisien restorting force (gaya pengembali ke titik setimbang) dan $\mathrm{F}_{0}$ adalah exsisting force / encountering force atau gaya luar yang bekerja pada kapal. Jika kapal berada pada kondisi air tenang (calm water) maka $\mathrm{F}_{0}$ adalah nol [1]

\section{Gelombang Reguler dan Irreguler}

Response Amplitude Operator (RAO) juga disebut sebagai transfer function suatu struktur pada gelombang reguler. RAO adalah fungsi dari amplitudo gerakan struktur terhadap amplitudo gelombang.[2]. Secara matematis persamaan RAO dapat dilihat pada tabel 2.1.

Gelombang irregular atau gelombang tak beraturan adalah gabungan dari beberapa gelombang beraturan yang dijumlahkan yang masing-masing memiliki frekuensi, tinggi, dan fase gelombang yang berbeda-beda. Dengan mengalikan RAO dengan spektrum gelombang pada gelombang tak beraturan maka akan didapatkan response dari struktur. Spektrum gelombang $(\omega)$ sebelumnya harus diubah terlebih dahulu menjadi spektrum encountered $\left(\omega_{\mathrm{e}}\right)$. Secara matematis dapat ditulis sebagai berikut :

$\omega_{q}=\omega-\frac{\omega^{2} V}{h} \cos \mu$

\section{E. Spektrum Gelombang}

Suatu gelombang timbul karena adanya angin. Semakin tinggi kecepatan angin, semakin lama angin berhembus dan semakin luar area hembusan angin, maka gelombang yang akan timbul juga semakin besar. Spektrum gelombang diperlukan dalam proses merancang kapal maupun bangunan lepas pantai, dimana untuk dapat memperkirakan seberapa besar gelombang maksimum yang ditimbulkan dimana kapal beroperasi atau di daerah tempat bangunan lepas pantai akan dibangun [3]

Spektrum gelombang yang dipakai dalam penelitian ini adalah spektrum JONSWAP untuk perairan tertutup/ kepulauan. Persamaan spektrum JONSWAP merupakan modifikasi dari persamaan spektrum Pierson-Morkowitz yang disesuaikan dengan kondisi laut yang ada. Persamaan spektrum JONSWAP dapat ditulis sebagai berikut :.

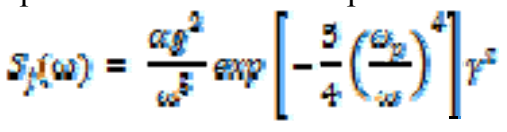


$\tau=\exp \left[\frac{\left(\omega-\omega_{2}^{2}\right)^{2}}{2 \sigma^{2} \omega_{p}^{2}}\right]$

Permintaan dasar dari desain konstruksi struktur apung adalah tersedianya perngoperasian dok yang aman dan efisien. Keandalan dari suatu sistem tambat suatu floating dock mejadi sangat penting terutama dengan memperhatikan access bridges, yang sifatnya didesain dengan asumsi bahwa sistem tambat yang ada akan mampu menjaga struktur tersebut berada pada area yang diizinkan baik akibat gerakan secara transversal maupun longitudinal. Gaya dari lingkungan serta reaksi dari struktur itu sendiri menjadi pertimbangan dalam mendesain sistem tambat. Oleh karena itu perlu perhitungan yang matang terkait desain dari sistem tambat dari struktur apung termasuk dok apung [7]

\section{F. Pengikatan Pada Dok Apung}

Permintaan dasar dari desain konstruksi struktur apung adalah tersedianya perngoperasian dok yang aman dan efisien. Keandalan dari suatu sistem tambat suatu floating dock mejadi sangat penting terutama dengan memperhatikan access bridges, yang sifatnya didesain dengan asumsi bahwa sistem tambat yang ada akan mampu menjaga struktur tersebut berada pada area yang diizinkan baik akibat gerakan secara transversal maupun longitudinal. Gaya dari lingkungan serta reaksi dari struktur itu sendiri menjadi pertimbangan dalam mendesain sistem tambat. Oleh karena itu perlu perhitungan yang matang terkait desain dari sistem tambat dari struktur apung termasuk dok apung. [7]

Pengikatan menggunakan rantai bersifat catenary.Sehingga ketentuan yang digunakan pada analisis untuk pengikatan bersifat catenary mengikuti persamaan

$$
x=\sigma \ln \left[\frac{g}{q}+\sqrt{\left(\frac{5}{g}\right)^{2}+1}\right]
$$

\section{METODOLOGI PENELITIAN}

\section{A. Diagram Alir Pengerjaan}

Pada penelitian ini diagram alir pengerjaan dapat dilihat pada Gambar Diagram Alir Pengerjaan.

\section{ANALISIS DAN PEMBAHASAN}

Dari data dok apung yang didapatkan, selanjutnya dibuat model dok apung dengan menggunakan perangkat lunak Maxsurf dan dilanjutkan dengan menggunakan perangkat lunak ansys aqwa. Hasilnya diperoleh geometri dari model dapat dilihat pada Gambar 4.1.

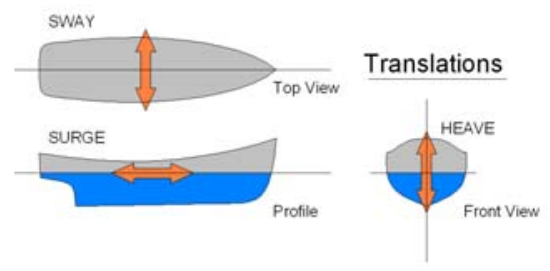

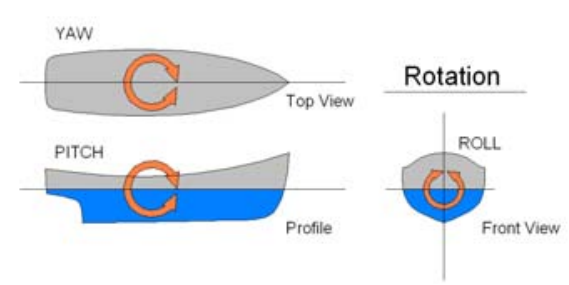

Gambar IV.1 Enam derajat kebebasan dari gerakan struktur apung atau kapal yakni surge, sway dan heave berupa gerkan translasi dan roll, pitch dan yaw berupa rotasi

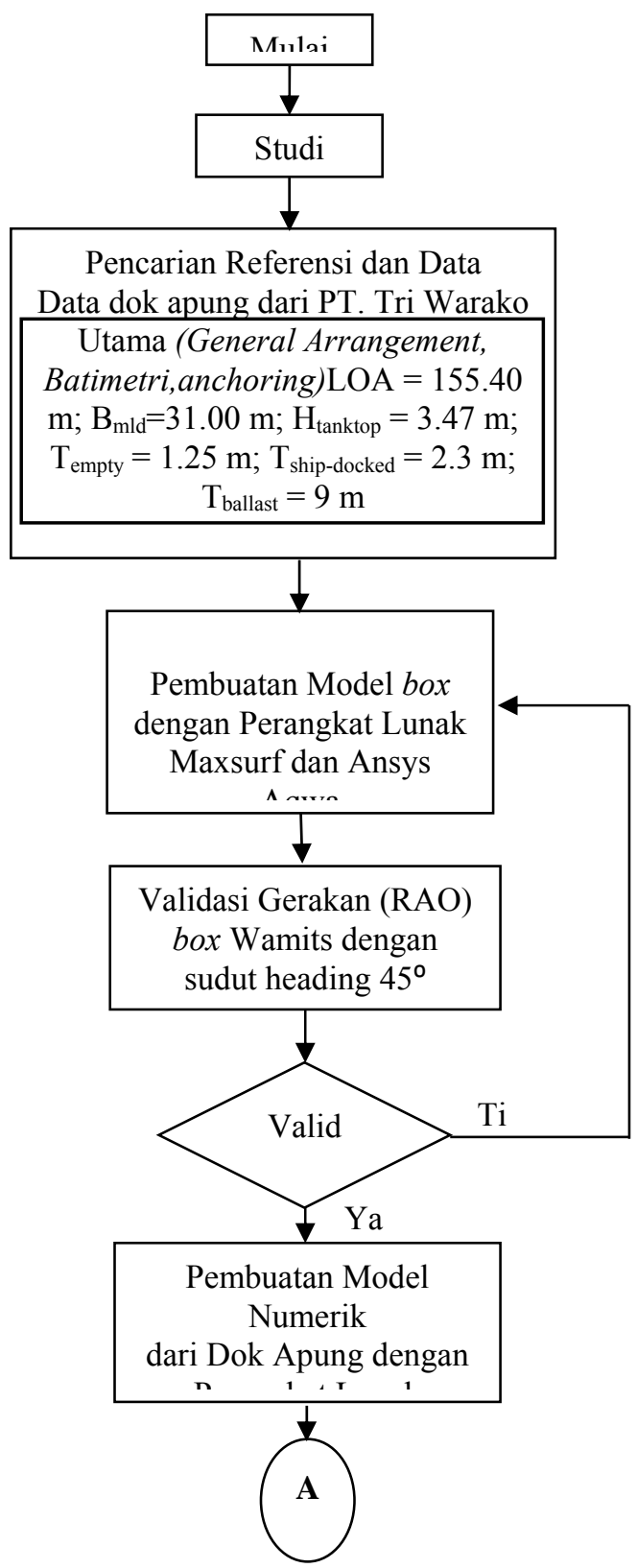




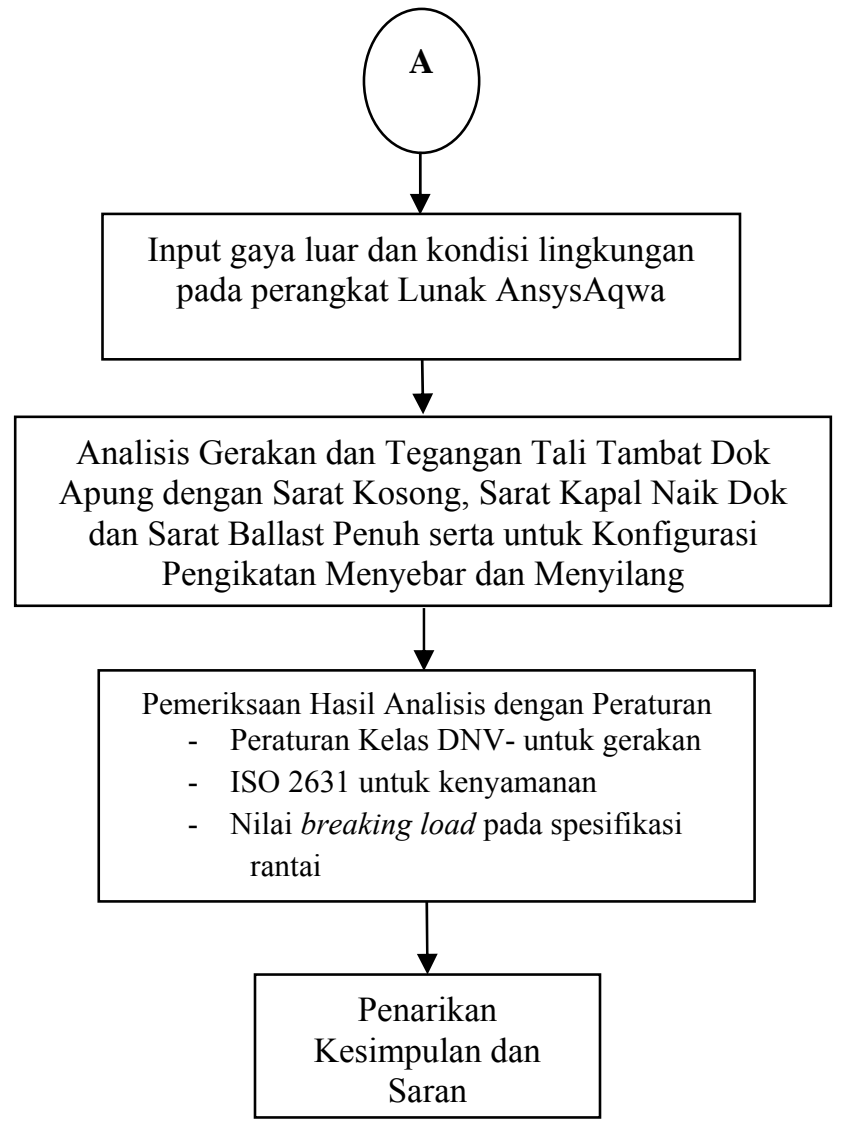

Gambar. Diagram Alir Pengerjaan

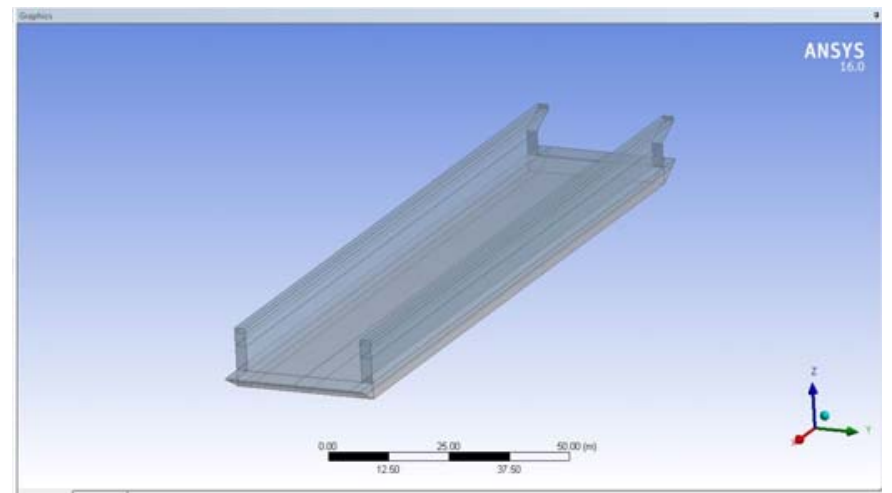

Gambar IV.2 Hasil pembuatan model dok apung sebelum dilakukan penambahan rantai

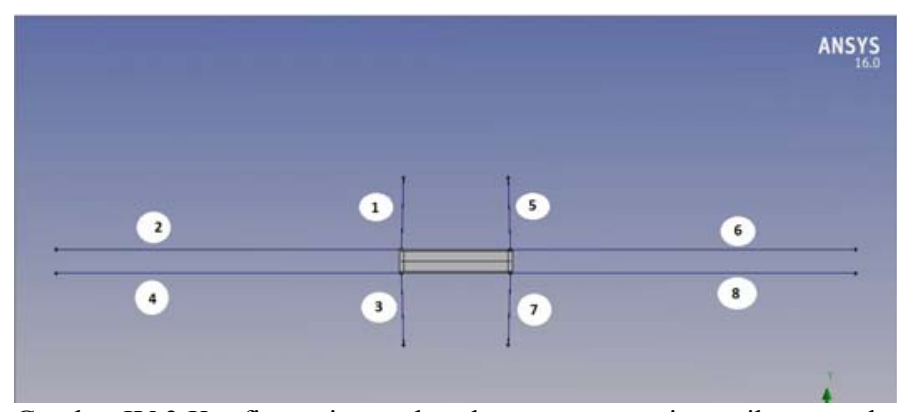

Gambar IV.3 Konfigurasi mnyebar dan nomor rantai pengikatan pada dok apung

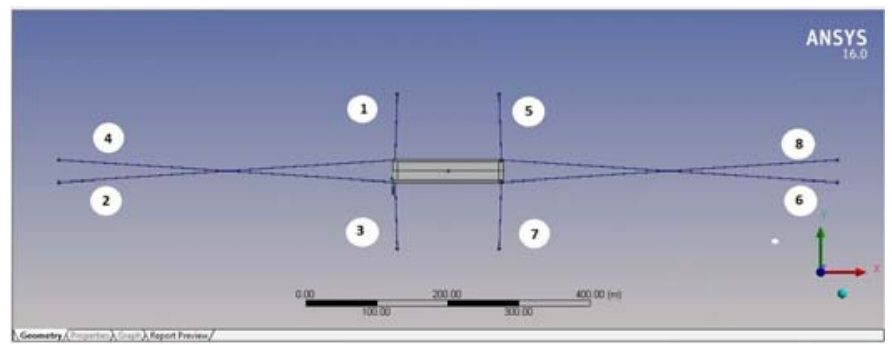

Gambar IV.4 Konfigurasi menyebar dan nomor rantai pengikatan pada dok apung

\begin{tabular}{ccc}
\multicolumn{3}{c}{ Tabel IV.1 Persamaan RAO } \\
\hline \hline No. & Gerakan & $\mathrm{RAO}$ \\
\hline 1 & Surge & $(\mathrm{xa} / \delta \mathrm{a})^{2}$ \\
2 & Sway & $(\mathrm{ya} / \delta \mathrm{a})^{2}$ \\
3 & Heave & $(\mathrm{za} / \delta \mathrm{a})^{2}$ \\
4 & Roll & $(\varnothing \mathrm{a} / \delta \mathrm{a})^{2}$ \\
5 & Pitch & $(\theta \mathrm{a} / \delta \mathrm{a})^{2}$ \\
6 & Yaw & $(\phi \mathrm{a} / \delta \mathrm{a})^{2}$ \\
\hline \hline
\end{tabular}

Tabel IV.2Respon gerakan maksimum pada kondisi kosong

\begin{tabular}{|c|c|c|c|c|c|}
\hline \multicolumn{6}{|c|}{ Structure Position Empty Dock } \\
\hline \multicolumn{2}{|c|}{ Global X $0^{0}(\mathrm{~m})$} & \multicolumn{2}{|c|}{ Global Y $90^{\circ}(\mathrm{m})$} & \multicolumn{2}{|c|}{ Global Z $90^{\circ}(\mathrm{m})$} \\
\hline Max & Min & Max & Min & Max & Min \\
\hline 0.038 & -0.039 & 0.0348 & -0.396 & 0.34 & -0.31 \\
\hline \multicolumn{2}{|c|}{ Global RX $90^{\circ}\left({ }^{\circ}\right)$} & \multicolumn{2}{|c|}{ Global RY $0^{0}\left({ }^{0}\right)$} & \multicolumn{2}{|c|}{ Global RZ $45^{\circ}\left(^{0}\right)$} \\
\hline Max & Min & Max & Min & Max & Min \\
\hline 1.93 & -2.06 & 0.10 & 0.086 & 0.0002 & -0.00023 \\
\hline
\end{tabular}

Tabel IV.3 Respon gerakan maksimum pada kondisi kapal naik dok

\begin{tabular}{|c|c|c|c|c|c|}
\hline \multicolumn{6}{|c|}{ Structure Position Docked-Ship Dock } \\
\hline \multicolumn{2}{|c|}{ Global X $0^{0}(\mathrm{~m})$} & \multicolumn{2}{|c|}{ Global Y $90^{\circ}(\mathrm{m})$} & \multicolumn{2}{|c|}{ Global Z $90^{\circ}(\mathrm{m})$} \\
\hline $\operatorname{Max}$ & Min & $\operatorname{Max}$ & Min & $\operatorname{Max}$ & Min \\
\hline 0.069 & -0.071 & 0.074 & -0.079 & 0.347 & -0.315 \\
\hline \multicolumn{2}{|c|}{ Global RX $90^{\circ}\left({ }^{0}\right)$} & \multicolumn{2}{|c|}{ Global RY $0^{0}\left({ }^{0}\right)$} & \multicolumn{2}{|c|}{ Global RZ $45^{\circ}\left({ }^{\circ}\right)$} \\
\hline $\operatorname{Max}$ & Min & $\operatorname{Max}$ & Min & $\operatorname{Max}$ & Min \\
\hline 1.83 & -1.96 & 0.154 & -0.149 & 0.00097 & -0.0009 \\
\hline
\end{tabular}

Tabel IV.4 Respon gerakan maksimum unruk kondisi balas penuh

\begin{tabular}{|c|c|c|c|c|c|}
\hline \multicolumn{6}{|c|}{ Structure Position Full-Ballast Dock } \\
\hline \multicolumn{2}{|c|}{ Global X $0^{\circ}(\mathrm{m})$} & \multicolumn{2}{|c|}{ Global Y $90^{\circ}(\mathrm{m})$} & \multicolumn{2}{|c|}{ Global Z $90^{\circ}(\mathrm{m})$} \\
\hline Max & Min & $\operatorname{Max}$ & Min & Max & Min \\
\hline 0.191 & -0.201 & 0.365 & -0.415 & 0.125 & -0.129 \\
\hline \multicolumn{2}{|c|}{ Global RX $90^{\circ}\left(^{0}\right)$} & \multicolumn{2}{|c|}{ Global RY $0^{0}\left({ }^{0}\right)$} & \multicolumn{2}{|c|}{ Global RZ $45^{\circ}\left({ }^{0}\right)$} \\
\hline $\operatorname{Max}$ & Min & $\operatorname{Max}$ & Min & Max & Min \\
\hline 0.388 & -0.379 & 0.059 & -0.058 & 0.208 & -0.204 \\
\hline
\end{tabular}


Tabel IV.5 Respon gerakan maksimum pada kondisi kosong

Structure Position Empty Dock

\begin{tabular}{|c|c|c|c|}
\hline \multicolumn{2}{|c|}{ Global x $0^{0}(\mathrm{~m})$} & \multicolumn{2}{|c|}{ Global Y $90^{\circ}(\mathrm{m})$} \\
\hline Max & Min & Max & Min \\
\hline 0.038 & -0.04 & 0.47 & -0.458 \\
\hline \multicolumn{2}{|c|}{ Global z $90^{\circ}(\mathrm{m})$} & \multicolumn{2}{|c|}{ Global RX $90^{\circ}\left({ }^{0}\right)$} \\
\hline Max & Min & Max & Min \\
\hline 0.349 & -0.296 & 1.95 & -2.06 \\
\hline \multicolumn{2}{|c|}{ Global RY $0^{0}\left({ }^{0}\right)$} & \multicolumn{2}{|c|}{ Global RZ $45^{\circ}\left({ }^{0}\right)$} \\
\hline Max & Min & Max & Min \\
\hline 0.172 & -0.166 & 0.155 & -0.155 \\
\hline
\end{tabular}

Tabel IV.6 Respon gerakan maksimum unruk kondisi kapal naik dok Structure Position Empty Dock

\begin{tabular}{cccc}
\hline \multicolumn{4}{c}{ Structure Position Empty Dock } \\
Global X $0^{\circ}(\mathrm{m})$ & Global Y $90^{\circ}(\mathrm{m})$ \\
\hline \hline Max & Min & Max & Min \\
\hline .069 & -0.071 & 0.697 & -0.717 \\
Global Z $90^{\circ}(\mathrm{m})$ & Global RX $90^{\circ}\left({ }^{0}\right)$ \\
Max & Min & Max & Min \\
0.346 & -0.319 & 1.80 & -1.99 \\
Global RY & $0^{\circ}\left({ }^{0}\right)$ & Global RZ $45^{\circ}\left({ }^{0}\right)$ \\
Max & Min & Max & Min \\
0.153 & -0.15 & 0.24 & -0.24 \\
\hline \hline
\end{tabular}

Tabel IV.7 Respon gerakan maksimum unruk kondisi balas penuh

\begin{tabular}{|c|c|c|c|}
\hline \multicolumn{4}{|c|}{ Structure Position Empty Dock } \\
\hline \multicolumn{2}{|c|}{ Global X $0^{0}(\mathrm{~m})$} & \multicolumn{2}{|c|}{ Global Y $90^{\circ}(\mathrm{m})$} \\
\hline Max & Min & Max & Min \\
\hline 2.31 & -2.24 & 0.357 & -0.414 \\
\hline \multicolumn{2}{|c|}{ Global Z $90^{\circ}(\mathrm{m})$} & \multicolumn{2}{|c|}{ Global RX $90^{\circ}\left({ }^{0}\right)$} \\
\hline Max & Min & Max & Min \\
\hline 0.273 & -0.291 & 0.388 & -0.375 \\
\hline \multicolumn{2}{|c|}{ Global RY $0^{0}\left({ }^{0}\right)$} & \multicolumn{2}{|c|}{ Global RZ $45^{\circ}\left({ }^{0}\right)$} \\
\hline Max & Min & Max & Min \\
\hline 0.271 & -0.265 & 1.03 & -1.17 \\
\hline
\end{tabular}

Tabel IV.8 Nilai percepatan gerak vertikal dok apung

\begin{tabular}{|c|c|c|c|c|c|c|}
\hline \multirow{2}{*}{$\begin{array}{l}\text { Kondisi } \\
\text { Dok }\end{array}$} & \multicolumn{2}{|c|}{$0^{0}$} & \multicolumn{2}{|c|}{$45^{0}$} & \multicolumn{2}{|c|}{$90^{\circ}$} \\
\hline & $\max$ & $\min$ & $\max$ & $\min$ & $\max$ & $\min$ \\
\hline Kosong & 0.022 & -0.024 & 0.023 & -0.022 & 0.208 & -0.211 \\
\hline $\begin{array}{l}\text { Kapal naik } \\
\text { dok }\end{array}$ & 0.020 & -0.023 & 0.027 & -0.024 & 0.181 & -0.210 \\
\hline $\begin{array}{l}\text { Balas } \\
\text { penuh }\end{array}$ & 0.009 & -0.010 & 0.008 & -0.007 & 0.056 & -0.050 \\
\hline
\end{tabular}

\section{A. Respon Gerakan Dok Apung}

Dari model yang telah dibuat selanjutnya dilakukan perhitungan terhadap gerakan dok apung akibat kondisi lingkungan berupa gelombang, angin dan arus. Untuk konfihurasi pengikatan, terdapat 2 konfigurasi yakni menyebar dan menyilang. Adapun konfigursi dan nomor tambatnya. Dalam melakukan analisis, percobaan pada perangkat lunak disetting untuk waktu percobaan minimum 3 jam. Hal tersebut diperlukan agar hasil yang diperoleh cukup akurat dan mewakili kondisi dari lingkungan sebenarnya yang berupa gelombang irregular.[4]

Untuk kofigurasi pengikatan menyebar didapatkan nilai maksimum untuk masing-masing sarat.

Tabel IV.1, IV.2, dan IV.3 di atas merupakan nilai maksimum untuk konfigurasi menyebar baik sudut $0^{\circ}, 45$ ${ }^{\circ}$ ataupun 90. Dari tabel di atas terlihat bahwa untuk gerakan surge (global $\mathrm{x}$ ) maksimum terjadi pada sudut gelombang datang $0^{\circ}$, sway (global y) maksimum terjadi pada sudut gelombang datang $90^{\circ}$, heave (global z) maksimum terjadi pada sudut gelombang datang $90^{\circ}$, roll (global rx) maksimum terjadi pada sudut gelombang datang $90^{\circ}$, pitch (global ry) maksimum terjadi pada sudut gelombang datang $0^{\circ}$, yaw (global rz) maksimum terjadi pada sudut gelombang datang $45^{\circ}$. Dari hasil tersebut kemudian dibandingkan dengan peraturan dari DNV-GL tentang gerakan maksimum dari kapal[5]. Hasilnya adalah seluruh gerakan tersebut berada di bawah dari batas yang diberikan oleh DNV- GL. Sehingga dapat disimpulkan bahwa gerakan dok apung tersebut aman.

Selanjutnya untuk konfigurasi menyilang dilakukan percobaan secara numerik. Dengan mengubah konfigurasi dari pengikatan dok apung seperti pada gambar IV.3 diperoleh hasil nilai gerakan maksimum untuk masing-masing sarat dapat di lihat pada tabel berikut

Tabel IV.4, IV.5 dan IV.6 di atas merupakan nilai maksimum untuk konfigurasi menyebar baik sudut $0^{\circ}, 45^{\circ}$ ataupun 90. Dari tabel di atas terlihat bahwa untuk gerakan surge (global $\mathrm{x}$ ) maksimum terjadi pada sudut gelombang datang $0^{\circ}$, sway (global y) maksimum terjadi pada sudut gelombang datang $90^{\circ}$, heave (global z) maksimum terjadi pada sudut gelombang datang $90^{\circ}$, roll (global rx) maksimum terjadi pada sudut gelombang datang $90^{\circ}$, pitch (global ry) maksimum terjadi pada sudut gelombang datang $0^{\circ}$, yaw (global rz) maksimum terjadi pada sudut gelombang datang $45^{\circ}$. Dari hasil tersebut kemudian dibandingkan dengan peraturan dari DNV-GL tentang gerakan maksimum dari kapal[5]. Hasilnya adalah seluruh gerakan tersebut berada di bawah dari batas yang diberikan oleh DNV- GL. Sehingga dapat disimpulkan bahwa gerakan dok apung tersebut aman

\section{B. Tegangan pada Rantai Pengikatan}

Untuk nilai tegangan, pada konfigurasi pengikatan dok apung menyebar, pada sarat kosong, nilai tegangan paling tinggi terjadi pada rantai nomor 3 dengan sudut datang gelombang $90^{\circ}$ yakni sebesar $801738 \mathrm{~N}$. Selanjutnya adalah pada rantai nomor 7 yang mendekati nilai tegangan dari rantai nomor 3 sebesar 801717 N. Untuk sarat kapal naik dok nilai 
tegangan paling tinggi terjadi pada rantai nomor 7 dengan sudut datang gelombang $90^{\circ}$ yakni sebesar $250255 \mathrm{~N}$. Selanjutnya adalah pada rantai nomor 3 yang mendekati nilai tegangan dari rantai nomor 7 sebesar $250226 \mathrm{~N}$. Untuk kondisi balas penuh nilai tegangan paling tinggi terjadi pada rantai nomor 7 dengan sudut datang gelombang $90^{\circ}$ yakni sebesar 1631936 N. Selanjutnya adalah pada rantai nomor 3 yang mendekati nilai tegangan dari rantai nomor 7 sebesar $1194929 \mathrm{~N}$.

Untuk nilai tegangan, pada konfigurasi pengikatan dok apung mnyilang, , pada sarat kosong nilai tegangan paling tinggi terjadi pada rantai nomor 1 dengan sudut datang gelombang $90^{\circ}$ yakni sebesar $1027345 \mathrm{~N}$. Selanjutnya adalah pada rantai nomor 5 yang mendekati nilai tegangan dari rantai nomor 3 sebesar 1027324 N. Pada sarat kapal naik dok nilai tegangan paling tinggi terjadi pada rantai nomor 3 dengan sudut datang gelombang $90^{\circ}$ yakni sebesar $498997.563 \mathrm{~N}$. Selanjutnya adalah pada rantai nomor 7 yang mendekati nilai tegangan dari rantai nomor 3 sebesar $498960.469 \mathrm{~N}$. tersebut nilai tegangan paling tinggi terjadi pada rantai nomor 7 dengan sudut datang gelombang $90^{\circ}$ yakni sebesar 2163322.75 N. Selanjutnya adalah pada rantai nomor 3 yang mendekati nilai tegangan dari rantai nomor 7 sebesar $2154434.75 \mathrm{~N}$.

Secara umum ketika sudut datang gelombang searah atau berlawan dengan sumbu Y rantai yang bernomor ganjil (rantai 1 , rantai 3 , rantai 5 , dan rantai 7) mengalami tegangan yang lebih besar karena menahan gerakan dari dok apung. Sebaliknya nilai tegangan pada rantai bernomor genap (rantai 2 , rantai 4, rantai 6 , dan rantai 8) lebih kecil karena tegak lurus dengan arah datangnya gelombang. Begitu pula ketika sudut datang gelombang searah atau berlawan dengan sumbu $\mathrm{X}$ nilai tegangan pada rantai bernomor genap (rantai 2, rantai 4, rantai 6, dan rantai 8) lebih besar karena menahan gerakan dari dok apung. Sebaliknya rantai yang bernomor ganjil (rantai 1, rantai 3, rantai 5, dan rantai 7) mengalami tegangan yang lebih kecil karena tegak lurus dengan arah datangnya gelombang

\section{Kenyamanan Dok Apung}

. Kenyamanan dok apung sendiri dipengaruhi oleh percepatan dari gerakan dok apung terutam pada gerakan heave. Dengan menggunakan perangkat lunak ansys aqwa dapat diketahui besarnya percepatan gerak dari dok apung untuk gerakan heave adalah sebagai berikut

Nilai maksimum untuk percepatan gerakan heave dok apung terjadi pada saat kondisi dok apung kosong dengan perceparan sebesar $0.208 \mathrm{~m} / \mathrm{s}^{2}$. Jika dibandingkan dengan standard dari ISO 2631 maka dapat disimpulkan bahwa dok apung masuk dalam kategori not uncomfortable atau dengan kata lain dok apung memiliki tingkat kenyamanan yang baik.

\section{KESIMPULAN DAN SARAN}

\section{A. Kesimpulan}

Dari hasil perhitungan dan analisis sebelumnya, dapat diambil kesimpulan sebagai berikut
1. Tegangan maksimum pada konfigurasi menyilang yakni $2163322.75 \mathrm{~N}$ dibandingkan dengan tegangan maksimum pada konfigurasi menyebar yang besarnya 1631936.75 N. Dibandingkan dengan tegangan maksimum (breaking load) pada rantai yakni sebesar $1370 \mathrm{kN}$ atau sebesar $1370000 \mathrm{~N}$ kedua nilai di atas tidak memenuhi (di atas breaking load). Sehingga untuk pemilihan rantai disarankan untuk memilih rantai dengan nilai breaking load yang lebih tinggi. Tetapi untuk kondisi kapal naik dok dan kondisi kosong nilai tegangan rantai masih memenuhi (di bawah breaking load). Hal tersebut dimungkinkan adanya pengaruh penambahan beban akibat jarak dasar laut dengan dok apung ketika kondisi ballast penuh karena ketika kedalaman laut ditambah, tegangan rantai yang terjadi berkurang.

2. Terjadi perbedaan nilai beban pada rantai pengikatan berupa tegangan (tension) antara konfigurasi menyebar dan konfigurasi menyilang. Beban maksimum rantai berupa tegangan pada konfigurasi menyilang lebih besar dibandingkan dengan tegangan maksimum pada konfigurasi menyebar. Keduanya sama-sama terjadi pada kondisi balas penuh dengan sudut datang gelombang $90^{\circ}$ dan pada rantai nomor 7. Sehingga untuk pemilihan rantai diperlukan rantai dengan nilai breaking load yang lebih besar.

3. Nilai maksimum untuk percepatan gerakan heave dok apung terjadi pada saat kondisi dok apung kosong dengan perceparan sebesar $0.208 \mathrm{~m} / \mathrm{s}^{2}$, sehingga masuk dalam kategori not uncomfortable atau dengan kata lain dok apung memiliki tingkat kenyamanan yang baik.

4. Respon gerakan yang terjadi masih memenuhi kriteria dari biro klasifikasi yakni untuk gerakan roll dan pitch

\section{B. Saran}

1. Hasil penelitian dapat dipertimbangkan untuk melakukan perencanaan dok apung terutama konfigurasi tambat dan jarak antara dok apung dengan dasar laut

2. Perlu dilakukan penelitian yang lebih dalam lagi terhadap pengaruh jarak antara dasar laut dengan dasar dok apung untuk mengetahui pengaruhnya terhadap gerakan dari dok apung untuk melihat adanya squat effect

\section{DAFTAR PUSTAKA}

[1] Battacharya, R. (1978) Dynamics of Marine Vehicles. U.S. Naval Academy, Annapolis: Marryland

[2] Chakrabarti, S. (1987) Hydrodynamic of Offshore Structures. Boston. USA: Computational Mechanics Publications Southampton

[3] Djatmiko, E. (2012). Perilaku dan Operabilitas Bangunan Laut di Atas Gelombang Acak. Surabaya: ITS Press.

[4] DNV GL. (2015). DNV-GL Offshore Standard: Mooring Position. DNV-GL

[5] GL Noble Denton (2010) Guidelines for Marines Transportation.Noble Denton Group Limited

[6] Sudira, B. P. (2014) Studi Karakteristik Gerakan dan Operabilitas Anjungan Pengeboran Semi-submersible dengan Dua Kolom Miring dan Ponton Berpenampang Persegi Empat.Surabaya. Teknik Kelautan ITS

[7] Tsinker, G. P.(2004) Port Engineering: Planning, Construction, Maintenance, and Security. New Jersey, Canada. John Wiley and Sons Inc.. 